\title{
WHEAT MiLl STREAM PROPERTIES FOR DisCRETE ELEMENT METHOD MODELING
}

\author{
A. Patwa, R. P. Kingsly Ambrose, H. Dogan, M. E. Casada
}

\begin{abstract}
A discrete phase approach based on individual wheat kernel characteristics is needed to overcome the limitations of previous statistical models and accurately predict the milling behavior of wheat. As a first step to develop a discrete element method (DEM) model for the wheat milling process, this study determined the physical and mechanical properties of wheat mill streams (wheat kernels, break stream, and wheat flour) required as input parameters. The parameters measured were particle size and size distribution, bulk density, Young's modulus, static and rolling coefficients of friction, and coefficient of restitution. The effect of moisture content (12\% to $16 \%$ wet basis) on these properties was evaluated. The density, Young's modulus, and coefficient of restitution tended to decrease while the coefficients of friction tended to increase with increasing moisture content of wheat kernels. The effect of moisture content on material properties was significant for break stream, but there was no significant $(p>0.05)$ material property change with moisture content for flour. It was concluded that moisture content had a greater significant effect on physical properties (bulk, true, and tapped densities and particle size) of the mill streams than it did on the mechanical properties (Young's modulus, coefficients of static and rolling friction, and coefficient of restitution).
\end{abstract}

Keywords. Moisture content, Physical properties, Wheat flour, Wheat mill streams.

$\mathrm{W}$ heat (Triticum spp.) is the one of the leading cereal grains that is produced, consumed, and traded in the world today (Oleson, 1994). In the past few decades, wheat production has nearly doubled; approximately $80 \%$ of this increase is the result of improved varieties and agronomic practices, while $20 \%$ is due to the increased area of production (Wrigley, 2009). Wheat is used in a wide variety of foods, including breads, pastries, cakes, cookies, confectionary, snack bars, and noodles, as well as animal feed. The majority of these products use wheat flour, the primary end-product of the wheat milling process. Processing generally involves milling the grain, either fully or partially, by separating the bran and germ from the endosperm so as to extract the maximum possible amount of endosperm as flour (Campbell et al., 2007). This is achieved by a series of size-reduction operations that include break roll systems, reduction roll systems, sifters, purifiers, etc. Irrespective of

Submitted for review in February 2014 as manuscript number FPE 10626; approved for publication by the Food \& Process Engineering Institute of ASABE in June 2014.

Mention of company or trade names is for description only and does not imply endorsement by the USDA. The USDA is an equal opportunity provider and employer.

Contribution No. 14-259-J of the Kansas State University Agricultural Experiment Station.

The authors are Abhay Patwa, ASABE Member, Graduate Student, R. P. Kingsly Ambrose, ASABE Member, Assistant Professor, and Hulya Dogan, Associate Professor, Department of Grain Science and Industry, Kansas State University, Manhattan, Kansas; Mark E. Casada, ASABE Member, Research Agricultural Engineer, USDA-ARS Center for Grain and Animal Health Research, Engineering and Wind Erosion Research Unit, Manhattan, Kansas. Corresponding author: R. P. Kingsly Ambrose, 312 Shellenberger Hall, Kansas State University. Manhattan, KS 66506; phone: 785-532-4091; e-mail: kingsly@ksu.edu. the end use of milled wheat, it is necessary to maintain the highest quality of the end-product flour.

Different milling systems are used for size reduction, including roller mills, hammer mills, and stone mills. Studies comparing the energy efficiency of the different milling techniques have indicated that roller milling is more efficient than other milling systems (Dziki and Laskowski, 2004). Different parameters play a role in determining the energy efficiency of a mill, and they directly correlate to the quality of flour produced. Broadly, these parameters can be divided into wheat physical properties and mill operational parameters. Grain properties include moisture content, grain hardness, particle size and size distribution, density, and coefficient of friction. Mill operational parameters include feed rate, roll speed differential, roll gap, and roll disposition (Fang et al., 1998).

Moisture content of the grain affects both its material properties and its milling behavior (Dziki et al., 2010). Wheat is generally milled in a moisture range of $15.5 \%$ to $16.5 \%$ for hard wheat and $15 \%$ to $15.5 \%$ for soft wheat (Fang, 1995). It has been observed that the specific grinding energy is highest at $16 \%$ to $17 \%$ moisture, whereas this value decreases at lower moisture values (Dziki and Laskowski, 2004). This difference is a result of variation in the mechanical properties of grain with varying moisture content (Dziki, 2008). Similar observations were made for decreasing strength properties with increasing moisture content (Zoerb and Hall, 1960), especially for hard wheat (Dziki et al., 2010; Delwiche, 2000). It was also found that coefficients of friction for wheat increased linearly with an increase in moisture content (Brubaker and Pos, 1965). Grain hardness is another important factor that determines the breakage behavior of grain during milling. It also dif- 
ferentiates wheat classes (Dziki et al., 2010; Delwiche, 2000; Fang and Campbell, 2002; Jirsa et al., 2008).

Mill operational parameters play a crucial role in energy consumption during first break milling and in the quality of flour produced. Each variable either directly or indirectly affects the process. Niernberger (1966) studied the effect of roll speed and roll diameter on first break grinding of wheat and found that the roll diameter had a significant effect on the particle size and ash content of the ground product. Subsequently, Fang (1995) found that feed rate played the most crucial role during first break grinding. In a similar study, Fang and Campbell (2002) found that using a dullto-dull roll disposition for first break milling gave a Ushaped distribution of particle size, while a sharp-to-sharp disposition gave a straight-line distribution for first break mill streams. These studies indicated the important effects of roll parameters on flour extraction percentage.

It would be a challenging task to monitor all variables so as to ensure production of high-quality flour. Computerbased models and simulations are an effective way of monitoring these variables, as they save time and reduce the effort required to control each variable independently. Many researchers have studied the effects of these variables on energy consumption during first break roller milling using various mathematical models based on stepwise regression statistical models. In a study on the effect of physical properties and operational parameters on size reduction of wheat, Fang (1995) found that the geometric mean particle size was positively correlated to the single kernel hardness of wheat and the roll gap. It was also found that the energy required per unit weight of sample was positively correlated with the single kernel hardness and inversely related to the roll gap (Fang, 1995). Pasikatan et al. (2001) also found that, of all parameters, kernel hardness and roll gap had the most significant effect on specific energy and break stream release based on linear statistical regression models. Fang et al. (1998) used neural network models to predict three physical properties of roller-milled wheat using different milling parameters and grain properties. Campbell et al. (2007) developed models to predict the performance of a roller mill based on breakage equations and wheat breakage. They studied the effects of different grain properties and operational parameters on first break milling of wheat. These models were successful in predicting the breakage characteristics of wheat, but they were also excessively complicated (Mateos-Salvador et al., 2011). Mateos-Salvador et al. (2011) developed a model for roller milling of wheat using the normalized Kumaraswamy breakage function. Although these studies developed a model to predict the wheat milling process, the nonuniform physical and mechanical characteristics of wheat kernels make it difficult to assume that wheat milling is a continuum process. Because most of these predictions were based on statistical models, they did not account for differences in wheat kernel properties. Therefore, a discrete phase approach based on individual wheat kernel characteristics is needed to accurately predict the milling behavior of wheat.

The discrete element method (DEM) mainly involves following the motions of particles during a process and modeling each collision between particles and between particles and their environment (Cleary, 2001). This enables better understanding of the complex phenomena related to the mechanics of granular materials and their processing. In order to simulate the process, relevant physical and interaction properties of the material should be known (Boac et al., 2010). However, the literature on the physical and mechanical properties of wheat mill streams is very limited. Therefore, the objective of this study was to determine the necessary physical and material properties of wheat mill streams (wheat kernel, 1st/2nd break mill stream, and wheat flour) at different moisture contents (12\% to $16 \%$, wet basis), which are required as input parameters in DEM.

\section{Methods And Methodology \\ PREPARATION OF SAMPLES}

Samples of three different classes of wheat, i.e., hard red winter (HRW), hard red spring (HRS), and soft red winter (SRW) wheat, were procured from commercial flour manufacturers. These three wheat classes were selected for their distinct hardness characteristics. The mill streams studied were the wheat kernel, 1st/2nd roll break stream, and wheat flour. Wheat milling involves separation of flour and other streams (such as bran and germ based on size and flour content) once the wheat kernels pass through the roller mill. Most flour manufacturers process wheat kernels through first and second roller mills (breaks) continuously for efficient flour separation without separating the components after the first roller mill (1st break). Therefore, in this study, break stream samples that passed through the first and second roller mills (without any intermittent separation) were used for property analyses. The roll parameters used for milling were: roll gap $=0.05 \mathrm{~mm}$ for first break and $0.025 \mathrm{~mm}$ for second break, speed differential $=2.5: 1$, roll disposition $=$ dull-to-dull, and feed rate $=1000 \mathrm{~kg} \mathrm{~h}^{-1}$. The moisture content of all samples was determined using AOAC Standard Procedure 925.10 (AOAC, 2000), which involves drying 2 to $3 \mathrm{~g}$ of sample in a hot-air oven for $60 \mathrm{~min}$ at $130^{\circ} \mathrm{C}$. Samples were conditioned to $12 \%, 14 \%$, and $16 \%$ moisture content (wet basis). Proper moisture adjustments for conditioning the samples were calculated based on sample dry matter contents (Kingsly et al., 2009). Proximate analysis and starch content determination were performed on the samples by an external lab to determine the chemical composition of the break stream and flour. The methods used included AOAC 934.10 for moisture (AOAC, 2006b), AOAC 984.13 for crude protein (AOAC, 2006e), AOAC 920.39 for crude fat (AOAC, 2006a), AOAC 978.10 for crude fiber (AOAC, 2006d), AOAC 942.05 for ash content (AOAC, 2006c), and AACC 7613.01 for starch content (AACC, 1999).

\section{Single Kernel ChaRACTERIZATION SYSTEM}

A Perten wheat hardness instrument (model SKCS 4100, Perten Instruments, Hagersten, Sweden) was used to determine single kernel characteristics. A 12 to 16 g sample was cleaned of foreign material and used for analysis. The instrument analyzes 300 kernels individually for diameter, 
weight, hardness, and moisture content. The measured diameter was reported as the average kernel size.

\section{Particle Size and Particle Size Distribution}

A Tyler-Rotap sieve shaker (model RX-29, W.S. Tyler, Mentor, Ohio) was used to measure the particle size and particle size distribution of the wheat break stream and flour samples based on ASABE Standard S319.4 (ASABE, 2008). A sample (100 g) was placed on the topmost sieve of a set of 14 sieves whose weights were already recorded and sieved for $10 \mathrm{~min}$. The mass of sample retained on each sieve was recorded, and the particle size was reported in terms of the geometric mean diameter $\left(d_{g_{w}}\right)$ and geometric standard deviation $\left(S_{g w}\right)$ using equations 1 and 2:

$$
\begin{gathered}
d_{g w}=\log ^{-1}\left[\frac{\sum_{i=1}^{n}\left(W_{i} \log d_{i}^{\prime}\right)}{\sum_{i=1}^{n} W_{i}}\right] \\
S_{g w} \approx \frac{1}{2} d_{g w}\left[\log ^{-1} S_{\log }-\left(\log ^{-1} S_{\log }\right)^{-1}\right]
\end{gathered}
$$

where $d_{g w}$ is the geometric mean diameter of particles by mass $(\mathrm{mm}), S_{\mathrm{log}}$ is the geometric standard deviation of the log-normal distribution by mass, $S_{g w}$ is the geometric standard deviation of particle diameter by mass $(\mathrm{mm}), W_{i}$ is the mass on the $i$ th sieve (g), $n$ is the number of sieves, and $d_{i}$ is the nominal aperture size of the $i$ th sieve $(\mathrm{mm})$.

For measuring the particle size of wheat flour, a laser diffraction technique was used (LA-910 laser scattering particle size distribution analyzer, Horiba, Ltd., Kyoto, Japan). Laser diffraction is a volume-based wet technique that involves diluting the sample by adding approximately $2 \mathrm{~g}$ of sample to $20 \mathrm{~mL}$ of distilled water in a centrifuge tube and shaking it thoroughly until the sample dissolves. The diluted sample was then poured into the reservoir tank of the instrument, which was filled with distilled water. A set of blades agitating at $400 \mathrm{rpm}$ further mixed the flour sample in the water to allow uniform dispersion of the particles in the dispersant. After agitation and ultrasonic vibration $(39 \mathrm{kHz})$, light from a He-Ne laser and tungsten lamp was passed through solution. Based on the angle of diffraction of the light scattered by the particles, the system used optical models and mathematical procedures to calculate the particle size of the sample (Horiba, 2008).

\section{Bulk Density}

A Winchester cup arrangement (Seedburo Equipment Co., Des Plaines, Ill.) was used to estimate the bulk density of the wheat kernels and mill streams. The samples were made to fall from a hopper into a cup from a height of $10 \mathrm{~cm}$. The cup was allowed to fill completely until excess sample began to overflow. The excess sample was removed by making a zigzag motion with a scrapper. The bulk density was calculated from the weight and volume of the sample.

\section{TAPPED DENSITY}

Tapped density, or compacted bulk density, is the ratio of mass to volume of the sample after it has been tapped a fixed number of times. An Autotap density analyzer (Quantachrome Instruments, Boynton Beach, Fla.) was used to measure the tapped density. A cylinder of known volume was filled with each sample, and the cylinder was then tapped 750 times $\left(260\right.$ taps $\left.\mathrm{min}^{-1}\right)$. The tapped density was calculated from the tapped volume and weight of the sample.

\section{TRUe Density}

True density of the mill stream samples was measured using a gas pycnometer (AccuPync II 1340, Micromeritics, Norcross, Ga.). Helium was used to fill the chamber containing the sample to determine the volume occupied by the particles. The density was calculated from the weight and volume occupied by the solid particles.

\section{YounG'S Modulus}

Young's modulus is the ratio of the stress produced in a body to the applied strain. Young's modulus and yield stress are important material properties that provide information about particle deformation behavior (Yap et al., 2008). A universal testing machine (UTM) (Instron 4465, Instron Co., Norwood, Mass.) was used to measure the Young's modulus of the wheat mill streams that included wheat kernels. A cylindrical die, $40 \mathrm{~mm}$ in diameter, and a close-fitting punch were used for this purpose. The die was filled with the sample, and a compressive force of $5 \mathrm{kN}$ was applied. The UTM recorded the applied force and the displacement produced in the material. Using the stress and strain in the sample, the Young's modulus was calculated using equation 3 :

$$
E=\left(\frac{F / A}{\Delta L / L}\right)
$$

where $E$ is the Young's modulus (MPa), $F$ is the force $(\mathrm{kN}), A$ is the area $\left(\mathrm{m}^{2}\right), L$ is the length (m), and $\Delta L$ is the change in length $(\mathrm{m})$. The average Young's modulus value was calculated from three replications.

\section{COEFFICIENT OF STATIC FRICTION}

The static friction coefficient $\left(\mu_{s}\right)$ between the particle and wall (a $30 \mathrm{~cm} \times 35 \mathrm{~cm}$ steel plate) was measured using a laboratory device comprised of an open-bottom container, a test weight, and a pulley system. A known weight of sample filled the open-bottom container, which was connected by the pulley system to a hanging cup. Weights were placed in the cup in small increments, and the end point was determined when the container with sample moved for a corresponding increase in weight. The coefficient of static friction was calculated as the ratio of the weight required to move the sample to the weight of the sample.

\section{COEFFICIENT OF ROLLING FRICTION}

An arrangement similar to that described by Garnayak et al. (2008) was used to measure the coefficient of rolling friction. The sample was poured onto a horizontal steel plate $(30 \mathrm{~cm} \times 35 \mathrm{~cm})$ so that it formed a cone. Using an 
attached manually driven screw, the inclination of the platform was slowly increased until the sample began to roll down (Jayas and Cenkowski, 2007). The angle of inclination $(\theta)$ at this point was determined using the height of the platform from the base and the base length. The coefficient of rolling friction $\left(\mu_{r}\right)$ was calculated as the tangent of the angle of inclination.

\section{COEFFICIENT OF RESTITUTION}

The coefficient of restitution $\left(C_{r}\right)$ is the change in kinetic energy of a particle when it collides with another object (static or kinetic). Measuring the coefficient of restitution is important for accurately predicting the deformation behavior and motion of grain particles after collision with other grain particles or with rollers. In developing a DEM model to account for the stress and deformation produced in wheat kernels during milling, coefficient of restitution values help in determining the change in kinetic energy of the particles. A drop test, as described by Bharadwaj et al. (2010), was performed to measure the $C_{r}$ of wheat mill stream particles. The 1 st/2nd break stream and flour samples were compacted into tablets $(9 \pm 0.5 \mathrm{~mm}$ diameter and $3.5 \pm 0.5 \mathrm{~mm}$ thickness) using a custom-made tablet press in the Department of Grain Science and Industry at Kansas State University. Using the press, a compressive force of about $200 \times$ $10^{5}$ to $250 \times 10^{5}$ psi was applied to samples of about $250 \mathrm{mg}$. To measure the coefficient of restitution, the samples (wheat kernels or tablets made from wheat mill streams and wheat flour) were dropped from an initial height $H_{0}$ onto a steel platform in a closed chamber. The tablets rebounded to a height $H_{1}$ after colliding with the surface. The complete motion of the sample was recorded with a camera (Exilim EX-F1, Casio Computer Co. Ltd., Tokyo, Japan) at $300 \mathrm{fps}$. Assuming a zero initial velocity of the sample, the coefficient of restitution was calculated as a function of the rebound height of the sample, as given by equation 4 :

$$
C_{r}=\sqrt{\frac{H_{1}}{H_{0}}}
$$

\section{Statistical Analysis}

The size, size distribution, density, and friction tests were performed in triplicate. The coefficient of restitution test was performed 25 times for samples from each mill stream without repeating the same sample. Wheat kernel hardness testing was carried out with a fixed weight of sample. Results were analyzed for statistical significance using SAS (ver. 9.3, SAS Institute, Inc., Cary, N.C.). The
Table 2. Wheat kernel characteristics. ${ }^{[\mathrm{a}]}$

\begin{tabular}{|c|c|c|c|c|}
\hline & $\begin{array}{l}\text { Moisture } \\
\text { Content } \\
\text { (\% w.b.) } \\
\end{array}$ & $\begin{array}{c}\text { Hardness } \\
\text { Index }\end{array}$ & $\begin{array}{c}\text { Weight } \\
\text { (mg) }\end{array}$ & $\begin{array}{l}\text { Size } \\
(\mu \mathrm{m})\end{array}$ \\
\hline \multicolumn{5}{|l|}{ HRW } \\
\hline & 12.10 & $62.14(17.86) \mathrm{a}$ & $28.70(9.80) \mathrm{a}$ & $2550(400) \mathrm{a}$ \\
\hline & 14.35 & $64.39(16.57) \mathrm{a}$ & $28.50(9.10) \mathrm{a}$ & $2590(400) \mathrm{a}$ \\
\hline & 15.93 & $62.97(16.52) \mathrm{a}$ & $29.00(8.50) \mathrm{a}$ & $2610(410) \mathrm{a}$ \\
\hline \multicolumn{5}{|l|}{$\overline{\mathrm{HRS}}$} \\
\hline & 12.00 & 79.39 (17.63) a & $27.60(9.40) \mathrm{a}$ & $2620(420) \mathrm{a}$ \\
\hline & 13.70 & $74.99(18.51) b$ & $27.90(9.40) \mathrm{a}$ & $2620(440) a$ \\
\hline & 15.48 & $76.16(17.40) \mathrm{ab}$ & $29.00(10.60) \mathrm{a}$ & $2680(430) \mathrm{a}$ \\
\hline \multicolumn{5}{|l|}{ SRW } \\
\hline & 11.82 & $13.74(22.97) b$ & $32.80(8.90) b$ & $2640(360) a$ \\
\hline & 13.58 & $14.83(21.71) b$ & $34.90(9.80) \mathrm{ab}$ & $2680(340) \mathrm{a}$ \\
\hline & 15.70 & $18.45(19.44) \mathrm{a}$ & $36.20(10.00) \mathrm{a}$ & $2720(360) \mathrm{a}$ \\
\hline $\begin{array}{l}\mathrm{H} \\
\text { te } \\
\text { th } \\
(\mathrm{p}\end{array}$ & $\begin{array}{l}\text { same colun } \\
\geq 0.05) \text {. }\end{array}$ & $\begin{array}{l}\text { winter; HRS = ha } \\
\text { entheses are stanc } \\
\text { for a given samp }\end{array}$ & $\begin{array}{l}\text { red spring, SRW } \\
\text { d deviations. The } \\
\text { indicates no signi }\end{array}$ & $\begin{array}{l}\text { soft red win- } \\
\text { ame letter in } \\
\text { cant difference }\end{array}$ \\
\hline
\end{tabular}

physical and mechanical properties were compared using Tukey's honestly significant difference test in SAS.

\section{RESULTS AND DisCUSSIONS}

Crude protein and fat content were lower for SRW samples compared to HRW and HRS samples, but the crude fiber and break stream ash content and starch were higher (table 1). There was no significant difference in the sample chemical composition except for the crude protein and break stream crude fiber content. The chemical composition of the break stream and flour depends on the mill operational parameters; hence, the composition of the wheat endosperm and bran also depends on the operational parameters. Furthermore, mill operators can vary the operational parameters to adjust the flour extraction rate, the load on the sifters, and the bran level in the flour, and that can also affect the chemical composition of the break stream and flour.

\section{Single Kernel Characterization System}

The hardness index is a parameter used to distinguish between hard and soft wheat classes. The hardness index of HRW and HRS wheat kernels was nearly three times that of SRW wheat kernels (table 2). The difference in hardness index can be attributed to the difference in the starchprotein matrix in the kernel. The hardness index for all three wheat classes tested varied only slightly with moisture (table 2). The weight of individual kernels varied slightly with moisture (table 2), and this variation was significant for SRW wheat kernels, implying that water molecules could more easily migrate into the kernel due to the

Table 1. Proximate analysis of wheat mill break stream and flour. ${ }^{\text {a] }}$

\begin{tabular}{|c|c|c|c|c|c|c|}
\hline & & $\begin{array}{c}\text { Crude Protein } \\
(\mathrm{w} / \mathrm{w} \%)\end{array}$ & $\begin{array}{c}\text { Crude Fat } \\
(\mathrm{w} / \mathrm{w} \%)\end{array}$ & $\begin{array}{c}\text { Crude Fiber } \\
(\mathrm{w} / \mathrm{w} \%)\end{array}$ & $\begin{array}{c}\text { Ash } \\
(\mathrm{w} / \mathrm{w} \%)\end{array}$ & $\begin{array}{c}\text { Starch } \\
(\mathrm{w} / \mathrm{w} \%)\end{array}$ \\
\hline \multirow[t]{3}{*}{ 1st/2nd Break Stream } & HRW & $11.46(0.34) b$ & $1.28(0.21) \mathrm{a}$ & $2.22(0.00) \mathrm{b}$ & $1.79(0.05) \mathrm{a}$ & $58.10(2.20) \mathrm{a}$ \\
\hline & HRS & $15.21(0.13) \mathrm{a}$ & $1.35(0.14) \mathrm{a}$ & $2.41(0.23) \mathrm{ab}$ & $1.80(0.12) \mathrm{a}$ & $60.17(0.49) \mathrm{a}$ \\
\hline & SRW & $9.85(0.11) \mathrm{c}$ & $1.24(0.19) \mathrm{a}$ & $2.88(0.02) \mathrm{a}$ & $1.89(0.00) \mathrm{a}$ & $65.98(3.08) \mathrm{a}$ \\
\hline \multirow[t]{3}{*}{ Flour } & HRW & $12.82(0.01) b$ & $0.39(0.07) \mathrm{a}$ & $0.12(0.09) \mathrm{a}$ & $0.65(0.01) \mathrm{a}$ & $93.92(3.18) \mathrm{a}$ \\
\hline & HRS & $16.58(0.04) \mathrm{a}$ & $0.37(0.04) \mathrm{a}$ & $0.27(0.02) \mathrm{a}$ & $0.67(0.04) \mathrm{a}$ & $89.27(2.98) \mathrm{a}$ \\
\hline & SRW & $10.72(0.06) \mathrm{c}$ & $0.33(0.01) \mathrm{a}$ & $0.38(0.06) \mathrm{a}$ & $0.57(0.03) \mathrm{a}$ & $96.39(2.82) \mathrm{a}$ \\
\hline
\end{tabular}

HRW = hard red winter; HRS = hard red spring, SRW = soft red winter. Values in parentheses are standard deviations. The same letter within the same column for a given sample indicates no significant difference $(\mathrm{p} \geq 0.05)$. 
weak starch-protein matrix, resulting in an increase in weight. Hard wheat, having tightly integrated cell structures, results in higher hardness index values than soft wheat (Turnbull and Rahman, 2002).

\section{Particle Size and Particle Size Distribution}

The particle size of mill streams depends to a significant extent on the milling method and wheat type (Hareland, 1994). The primary purpose of first break milling is to break open the wheat kernel, yielding bran and endosperm particles with minimum bran breakage. This implies that 1st/2nd break would have a larger particle size and size distribution compared to the other mill stream products, since the primary composition is bran and flour. For the 1st/2nd break streams of the three different wheat classes, the SRW break stream had the smallest particle size, and the HRW break stream had the largest (table 3 ). This can be attributed to the difference in the hardness index of the different wheat classes. SRW wheat kernels, having the lowest hardness index, break into a greater proportion of smaller particles compared to hard wheat kernels (Fang and Campbell, 2002). Cohesion and agglomeration were not as evident in the HRW and HRS flours as they were in the SRW flour. The difference in mean particle size for each of the $1 \mathrm{st} / 2$ nd break streams can be attributed to the difference in kernel hardness (Dziki, 2008).

From the particle size values of the flours, obtained using the laser diffraction technique, we observed that there was no significant difference in the particle size of flour with moisture content within the same wheat class, even though the particle size increased (table 3 ). The average particle size ranged from 37 to $52 \mu \mathrm{m}$ for the flours from the evaluated wheat classes. From the cumulative distribution of the laser diffraction analysis, it was observed that at least $90 \%$ of the flour particles were in the range of 2 to
Table 3. Particle size and size distribution of wheat mill break stream and flour at different moisture content. ${ }^{[\mathrm{a}]}$

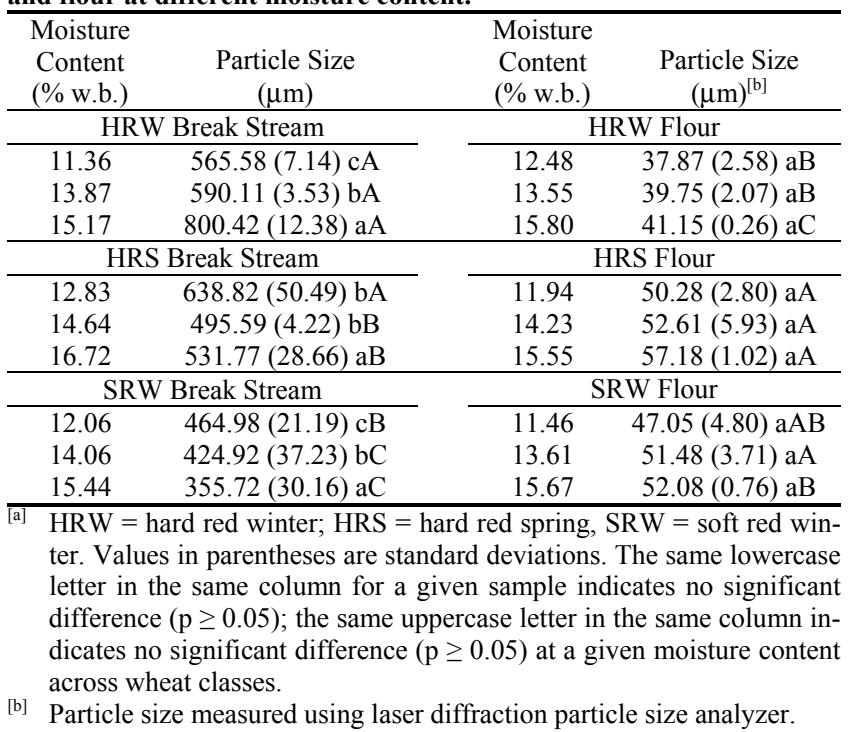

$50 \mu \mathrm{m}$ (fig. 1). Glenn and Saunders (1990) reported that starch-protein adhesion and intracellular spaces varied due to the starch-protein matrix continuity in the endosperm, resulting in variation in the particle size distributions of different wheat classes. As a result, a wide distribution of particle sizes was noticed, ranging from 2 to $400 \mu \mathrm{m}$. The mean particle size of the SRW flour was higher or comparable with the HRW and HRS flour particles due to higher cohesion between the SRW flour particles (Neel and Hoseney, 1984; Patwa et al., 2014). Similar results were observed by Hareland (1994) in a study on the evaluation of particle size of flour from different wheat classes.

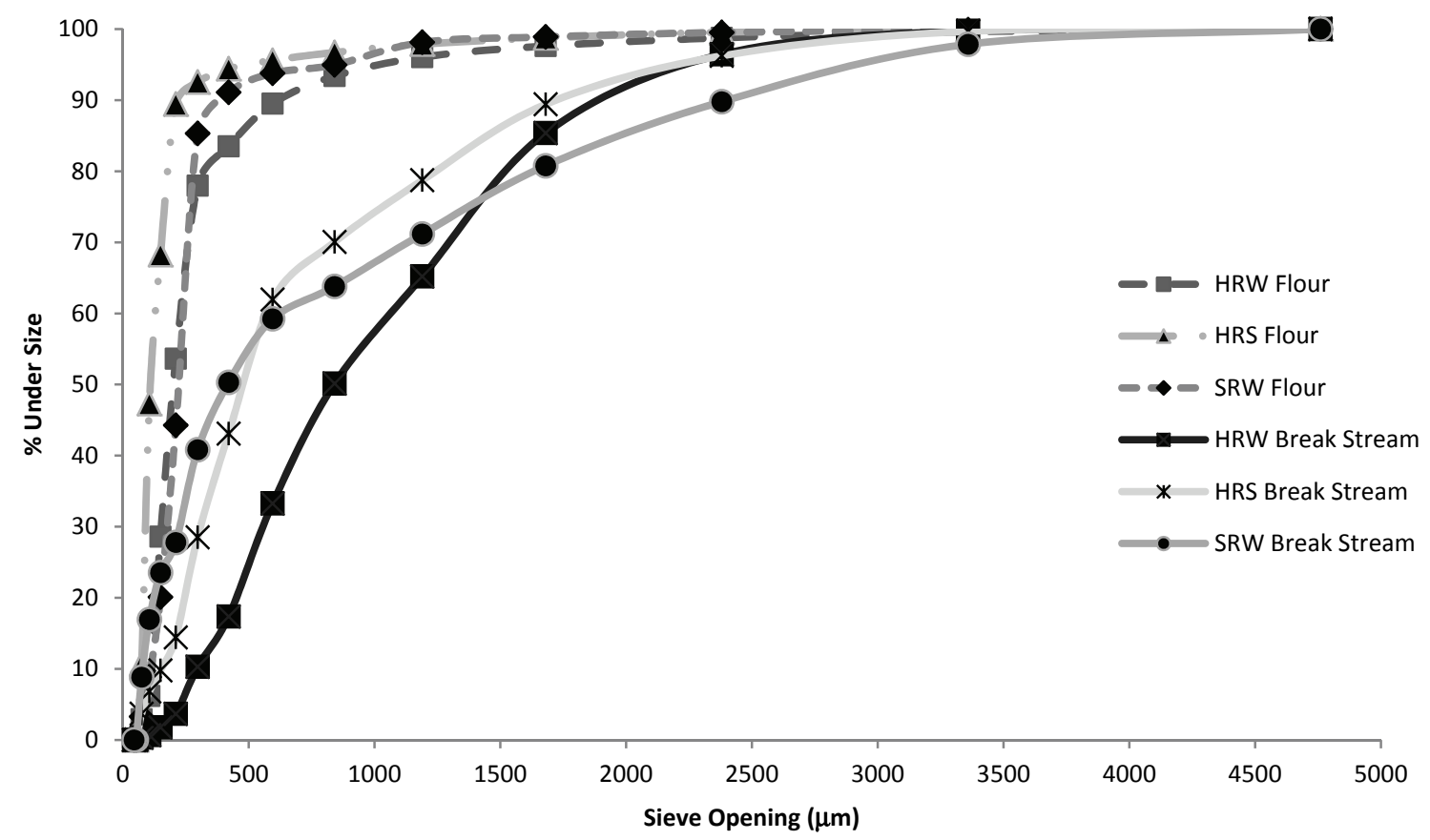

Figure 1. Cumulative particle size distribution of wheat mill break streams and flour at $16 \%$ moisture content. 


\section{BuLK DENSITY}

The bulk density for wheat kernels decreased in the range of about $20 \mathrm{~kg} \mathrm{~m}^{-3}$ with increasing moisture from $12 \%$ to $16 \%$ (w.b.) for kernels from all three wheat classes (table 4). The decrease in density was due to the corresponding increase in mass due to water addition being lower than the corresponding increase in volume occupied by the grains. Similar linear negative relationships of bulk density to moisture content have been found for different seeds and grains, such as barley and jatropha seed (Garnayak et al., 2008; Ozturk and Esen, 2008). The bulk densities of the 1st/2nd break stream and flour did not display a similar trend (tables 5 and 6). Instead, the bulk density of the break stream increased with increasing moisture content, but the increase was not statistically significant ( $\mathrm{p} \geq 0.05$; table 5 ). This observed trend was due to the composition of the $1 \mathrm{st} / 2 \mathrm{nd} \mathrm{break}$ stream, which comprised of a mix of bran and flour particles. As a result, addition of water led to swelling of the endosperm particles, resulting in a lower increase in volume compared to the mass of the break stream.

Similar to the 1st/2nd break stream, the flour displayed decreasing values of bulk density when the moisture content increased from $12 \%$ to $14 \%$. However, when the moisture content was increased further to $16 \%$, the bulk density also increased. Subramanian and Viswanathan (2007) found that the bulk density of different millet flours increased with moisture content.

\section{TAPPED DENSITY}

The tapped or compressed bulk density of wheat kernels decreased with an increase in moisture (table 4). This was possibly due to the increase in mass from moisture addition. The tapping motion results in a reduction of the volume occupied by the samples because the grains repack themselves into void spaces. Apparently, this decrease in volume due to tapping was less than the increase in grain mass due to moisture addition, resulting in the decreased tapped density.

While the wheat kernels displayed a negative relationship between tapped density and moisture content, this was not the case for the $1 \mathrm{st} / 2$ nd break stream and flour samples. Comparing the tapped density values for the different break streams at each moisture level, the values did not show any specific trend across wheat classes (table 5). This behavior can be attributed to the mixed composition of the break stream, which contained partially milled bran particles that had been separated from the endosperm as well as endosperm fragments. Thus, the break stream was comprised of large-size bran particles as well as smaller endosperm particles. As a result, during tapping of the samples, the smaller flour particles settle into the void spaces, resulting in a volume decrease. However, due to the presence of larger bran particles, the decrease in volume of the bulk sample was not significant. Because the quantity and percentage of bran and endosperm in a given replicate is highly variable, the

Table 4. Property values of HRW, HRS and SRW wheat kernels at different moisture contents. ${ }^{\text {[a] }}$

\begin{tabular}{|c|c|c|c|c|c|c|c|}
\hline $\begin{array}{c}\text { Moisture } \\
\text { Content } \\
\text { (\% w.b.) }\end{array}$ & $\begin{array}{c}\text { Bulk } \\
\text { Density } \\
\left(\mathrm{kg} \mathrm{m}^{-3}\right)\end{array}$ & $\begin{array}{l}\text { Tapped } \\
\text { Density } \\
\left(\mathrm{kg} \mathrm{m}^{-3}\right)\end{array}$ & $\begin{array}{c}\text { True } \\
\text { Density } \\
\left(\mathrm{kg} \mathrm{m}^{-3}\right)\end{array}$ & $\begin{array}{l}\text { Young's } \\
\text { Modulus } \\
\text { (MPa) }\end{array}$ & $\begin{array}{c}\text { Coefficient } \\
\text { of Static } \\
\text { Friction }\end{array}$ & $\begin{array}{c}\text { Coefficient } \\
\text { of Rolling } \\
\text { Friction }\end{array}$ & $\begin{array}{c}\text { Coefficient } \\
\text { of Restitution }\end{array}$ \\
\hline \multicolumn{8}{|l|}{ HRW } \\
\hline 12.10 & $779.07(0.10) \mathrm{aA}$ & $820.94(4.14) \mathrm{aA}$ & $1422.71(1.66) \mathrm{aB}$ & $15.88(2.53) \mathrm{aA}$ & $0.38(0.03) \mathrm{aA}$ & $0.19(0.01) \mathrm{aA}$ & $0.33(0.03) \mathrm{aB}$ \\
\hline 14.35 & $767.74(0.47) \mathrm{bB}$ & $814.21(1.94) \mathrm{aA}$ & $1419.86(0.77) \mathrm{bB}$ & $14.87(1.38) \mathrm{aA}$ & $0.39(0.03) \mathrm{aA}$ & $0.19(0.04) \mathrm{aA}$ & $0.32(0.04) \mathrm{aA}$ \\
\hline 15.93 & $760.26(1.60) \mathrm{cA}$ & $803.10(4.51) \mathrm{bA}$ & $1416.40(2.29) \mathrm{cB}$ & $12.75(0.50) \mathrm{aA}$ & $0.40(0.03) \mathrm{aA}$ & $0.20(0.01) \mathrm{aA}$ & $0.32(0.03) \mathrm{aA}$ \\
\hline \multicolumn{8}{|l|}{ HRS } \\
\hline 12.00 & $783.85(1.97) \mathrm{aA}$ & 823.38 (5.67) aA & $1426.05(0.76) \mathrm{aA}$ & $16.52(1.05) \mathrm{aA}$ & $0.38(0.03) \mathrm{aA}$ & $0.17(0.02) \mathrm{bA}$ & $0.34(0.03) \mathrm{aB}$ \\
\hline 13.70 & $778.70(0.41) \mathrm{bA}$ & $816.00(3.32) \mathrm{aA}$ & $1422.12(1.34) \mathrm{bA}$ & $15.35(0.64) \mathrm{abA}$ & $0.39(0.02) \mathrm{aA}$ & $0.19(0.003)$ abA & $0.33(0.02) \mathrm{aA}$ \\
\hline 15.48 & $762.73(2.56) \mathrm{cA}$ & $806.49(9.79) \mathrm{aA}$ & $1421.08(0.98) \mathrm{bA}$ & $13.83(0.21) \mathrm{bA}$ & $0.41(0.04) \mathrm{aA}$ & $0.24(0.02) \mathrm{aA}$ & $0.33(0.03) \mathrm{aA}$ \\
\hline \multicolumn{8}{|l|}{ SRW } \\
\hline 11.82 & $760.53(3.07) \mathrm{aB}$ & $797.20(3.81) \mathrm{aB}$ & $1383.43(1.67) \mathrm{aC}$ & $14.75(0.93) \mathrm{aA}$ & $0.39(0.03) \mathrm{bA}$ & $0.18(0.01) \mathrm{bA}$ & $0.38(0.05) \mathrm{aA}$ \\
\hline 13.58 & $756.28(0.89) \mathrm{aC}$ & $787.51(2.93)$ abB & $1378.33(1.01) \mathrm{bC}$ & $13.68(0.21) \mathrm{aA}$ & $0.43(0.02) \mathrm{abA}$ & $0.18(0.02) \mathrm{bA}$ & $0.35(0.03)$ abA \\
\hline 15.70 & 743.08 (1.39) bB & 780.39 (6.39) bB & $1371.43(1.83) \mathrm{cC}$ & $12.47(1.70) \mathrm{aA}$ & $0.47(0.03) \mathrm{aA}$ & $0.24(0.01) \mathrm{aA}$ & $0.33(0.02) \mathrm{bA}$ \\
\hline
\end{tabular}

Table 5. Property values of wheat mill break stream samples. ${ }^{\text {|a] }}$

\begin{tabular}{|c|c|c|c|c|c|c|c|}
\hline $\begin{array}{c}\text { Moisture } \\
\text { Content } \\
(\% \text { w.b. })\end{array}$ & $\begin{array}{c}\text { Bulk } \\
\text { Density } \\
\left(\mathrm{kg} \mathrm{m}^{-3}\right)\end{array}$ & $\begin{array}{l}\text { Tapped } \\
\text { Density } \\
\left(\mathrm{kg} \mathrm{m}^{-3}\right)\end{array}$ & $\begin{array}{c}\text { True } \\
\text { Density } \\
\left(\mathrm{kg} \mathrm{m}^{-3}\right)\end{array}$ & $\begin{array}{l}\text { Young's } \\
\text { Modulus } \\
(\mathrm{MPa})\end{array}$ & $\begin{array}{c}\text { Coefficient } \\
\text { of Static } \\
\text { Friction }\end{array}$ & $\begin{array}{c}\text { Coefficient } \\
\text { of Rolling } \\
\text { Friction }\end{array}$ & $\begin{array}{c}\text { Coefficient } \\
\text { of Restitution }\end{array}$ \\
\hline \multicolumn{8}{|l|}{ HRW } \\
\hline 11.36 & 457.80 (3.19) bA & $495.46(17.84) \mathrm{bB}$ & $1453.26(0.44) \mathrm{aB}$ & $0.39(0.06) \mathrm{aA}$ & $0.33(0.01) \mathrm{bA}$ & $0.17(0.01) b C$ & $0.27(0.03) \mathrm{bA}$ \\
\hline 13.87 & $487.33(5.10) \mathrm{abA}$ & $591.08(49.86) \mathrm{aA}$ & $1449.86(1.23) \mathrm{bB}$ & $0.43(0.16) \mathrm{aA}$ & $0.36(0.01) \mathrm{abA}$ & $0.18(0.00) \mathrm{bB}$ & $0.30(0.02) \mathrm{abA}$ \\
\hline 15.17 & $511.44(28.18) \mathrm{aA}$ & $562.70(6.76) \mathrm{abB}$ & $1430.89(1.77) \mathrm{cB}$ & $0.52(0.14) \mathrm{aA}$ & $0.37(0.02) \mathrm{aA}$ & $0.23(0.02) \mathrm{aB}$ & $0.31(0.02) \mathrm{aA}$ \\
\hline \multicolumn{8}{|l|}{ HRS } \\
\hline 12.83 & $459.98(8.38) \mathrm{aA}$ & $590.65(57.65) \mathrm{aA}$ & $1442.43(1.47) \mathrm{aC}$ & $0.17(0.09) \mathrm{aB}$ & $0.33(0.03) \mathrm{aA}$ & $0.21(0.01) \mathrm{bB}$ & $0.27(0.03) \mathrm{bA}$ \\
\hline 14.64 & $458.35(4.28) \mathrm{aB}$ & $535.14(38.40) \mathrm{aA}$ & $1437.39(2.51) \mathrm{aC}$ & $0.25(0.06) \mathrm{aAB}$ & $0.36(0.01) \mathrm{aA}$ & $0.26(0.03) \mathrm{bA}$ & $0.30(0.03) \mathrm{abA}$ \\
\hline 16.72 & $472.53(26.50) \mathrm{aA}$ & $551.28(11.09) \mathrm{aB}$ & $1430.89(1.77) \mathrm{bB}$ & $0.41(0.26) \mathrm{aA}$ & $0.37(0.04) \mathrm{aA}$ & $0.31(0.03) \mathrm{aA}$ & $0.32(0.04) \mathrm{aA}$ \\
\hline \multicolumn{8}{|l|}{$\overline{\text { SRW }}$} \\
\hline 12.06 & $463.40(10.26) \mathrm{aA}$ & 574.79 (10.89) bAB & 1464.15 (1.59) aA & $0.06(0.01) \mathrm{bB}$ & $0.34(0.03) \mathrm{aA}$ & $0.26(0.02) \mathrm{bA}$ & $0.25(0.02) \mathrm{bA}$ \\
\hline 14.06 & $447.97(5.22) \mathrm{aB}$ & $555.82(24.97) \mathrm{bA}$ & $1457.36(0.60) \mathrm{bA}$ & $0.08(0.005) \mathrm{bB}$ & $0.37(0.01) \mathrm{aA}$ & $0.26(0.01) \mathrm{abA}$ & $0.29(0.04) \mathrm{aA}$ \\
\hline 15.44 & $476.72(16.75) \mathrm{aA}$ & $621.70(7.65) \mathrm{aA}$ & $1450.51(1.28) \mathrm{cA}$ & $0.12(0.01) \mathrm{aA}$ & $0.37(0.04) \mathrm{aA}$ & $0.31(0.03) \mathrm{aA}$ & $0.30(0.03) \mathrm{aA}$ \\
\hline
\end{tabular}


Table 6. Property values of HRW, HRS and SRW wheat flour at different moisture contents. ${ }^{\text {|a| }}$

\begin{tabular}{|c|c|c|c|c|c|c|c|}
\hline $\begin{array}{c}\text { Moisture } \\
\text { Content } \\
\text { (\% w.b.) }\end{array}$ & $\begin{array}{c}\text { Bulk } \\
\text { Density } \\
\left(\mathrm{kg} \mathrm{m}^{-3}\right)\end{array}$ & $\begin{array}{l}\text { Tapped } \\
\text { Density } \\
\left(\mathrm{kg} \mathrm{m}^{-3}\right)\end{array}$ & $\begin{array}{c}\text { True } \\
\text { Density } \\
\left(\mathrm{kg} \mathrm{m}^{-3}\right)\end{array}$ & $\begin{array}{l}\text { Young's } \\
\text { Modulus } \\
(\mathrm{MPa}) \\
\end{array}$ & $\begin{array}{c}\text { Coefficient } \\
\text { of Static } \\
\text { Friction } \\
\end{array}$ & $\begin{array}{c}\text { Coefficient } \\
\text { of Rolling } \\
\text { Friction }\end{array}$ & $\begin{array}{c}\text { Coefficient } \\
\text { of Restitution }\end{array}$ \\
\hline \multicolumn{8}{|l|}{ HRW } \\
\hline 12.48 & $519.75(10.70) \mathrm{bA}$ & $693.29(37.86) \mathrm{aAB}$ & $1475.51(0.27) \mathrm{aB}$ & $0.12(0.03) \mathrm{bB}$ & $0.45(0.03) \mathrm{aA}$ & $0.50(0.02) \mathrm{aA}$ & $0.26(0.02) \mathrm{bB}$ \\
\hline 13.55 & $533.86(8.20) \mathrm{bB}$ & 691.29 (4.87) aB & $1470.33(0.70) \mathrm{bB}$ & $0.21(0.01) \mathrm{bA}$ & $0.43(0.04) \mathrm{aA}$ & $0.55(0.03) \mathrm{aA}$ & $0.27(0.02) \mathrm{abB}$ \\
\hline 15.80 & $570.50(1.94) \mathrm{aA}$ & $725.58(2.13) \mathrm{aA}$ & $1467.64(1.28) \mathrm{cB}$ & $1.55(0.63) \mathrm{aA}$ & $0.45(0.03) \mathrm{aA}$ & $0.51(0.02) \mathrm{aA}$ & $0.30(0.04) \mathrm{aB}$ \\
\hline \multicolumn{8}{|l|}{$\begin{array}{l}\text { HRS } \\
\end{array}$} \\
\hline 11.94 & $572.18(5.55) \mathrm{aA}$ & $730.42(3.02) \mathrm{aA}$ & $1465.34(0.27) \mathrm{aC}$ & $0.87(0.41) \mathrm{bAB}$ & $0.34(0.02) \mathrm{bB}$ & $0.32(0.02) \mathrm{aC}$ & $0.30(0.01) \mathrm{bA}$ \\
\hline 14.23 & $566.93(2.48) \mathrm{aA}$ & $701.50(3.41) \mathrm{bA}$ & $1460.16(0.45) \mathrm{bC}$ & $1.87(0.47) \mathrm{abA}$ & $0.36(0.01) \mathrm{aB}$ & $0.50(0.02) \mathrm{aA}$ & $0.31(0.03) \mathrm{bA}$ \\
\hline 15.55 & $565.63(2.54) \mathrm{aA}$ & $698.97(3.24) \mathrm{bB}$ & $1449.58(1.12) \mathrm{cC}$ & $3.31(0.84) \mathrm{aA}$ & $0.41(0.02) \mathrm{aA}$ & $0.52(0.01) \mathrm{bA}$ & $0.38(0.04) \mathrm{aA}$ \\
\hline \multicolumn{8}{|l|}{ SRW } \\
\hline 11.46 & 440.07 (3.11) bC & $653.41(7.33) \mathrm{aB}$ & $1488.27(0.96) \mathrm{aA}$ & $0.06(0.03) \mathrm{aA}$ & $0.44(0.02) \mathrm{aA}$ & $0.39(0.01) \mathrm{bB}$ & $0.28(0.02) \mathrm{aAB}$ \\
\hline 13.61 & $440.27(5.98) \mathrm{bC}$ & $630.46(2.21) b C$ & $1476.73(1.35) \mathrm{bA}$ & $0.05(0.02) \mathrm{aA}$ & $0.45(0.01) \mathrm{aA}$ & $0.40(0.05) \mathrm{abB}$ & $0.30(0.02) \mathrm{aA}$ \\
\hline 15.67 & $460.51(1.25) \mathrm{aB}$ & $621.68(8.03) \mathrm{bC}$ & $1470.10(0.95) \mathrm{cA}$ & $0.08(0.02) \mathrm{aA}$ & $0.47(0.02) \mathrm{aA}$ & $0.48(0.03) \mathrm{aA}$ & $0.31(0.07) \mathrm{aB}$ \\
\hline
\end{tabular}

trend was not definite, and the standard deviation was large. For the HRS and SRW flours, the tapped density decreased with increasing moisture (table 6). The wider particle size distribution of the flour samples could have led to the large standard deviations observed for the tapped density values.

\section{True Density}

The true density for all samples, (wheat kernels, break streams, and flour) decreased with increasing moisture content (tables 4 through 6). The addition of moisture to the kernels increased the mass as well as the volume. The increase in volume influenced the true density of the kernels more than the increasing mass did and resulted in a significant decrease in true density in the range of 10 to $20 \mathrm{~kg} \mathrm{~m}^{-3}$. We observed a lower true density value for SRW wheat kernels compared to the hard wheat kernels. Urena et al. (2002) reported that the average true density of hard wheat at $9.09 \%$ moisture was $1420 \mathrm{~kg} \mathrm{~m}^{-3}$. Although the density values of soft wheat reported by Chang (1988) were higher than the values obtained in this study, those for hard wheat were in a similar range.

For the break stream and flour samples, there was a significant decrease $(p \leq 0.05)$ in the true density with the change in moisture content (table 5). Addition of water causes starch granules to swell, increasing their volume and decreasing their density. Because flour particles are made up of starch and protein, the decrease in density could be due to swelling of the starch-protein matrix with addition of water.

\section{YounG's Modulus}

Young's modulus measures the stress-strain characteristics of a material. These characteristics, along with other mechanical properties, can be used to predict the breakage behavior and describe the grinding process for the material. The Young's modulus value for wheat kernel samples decreased with increasing moisture for HRS wheat kernels but did not show a significant trend for HRW and SRW wheat kernels (table 4). The Young's modulus value decreased because addition of moisture made the endosperm softer while toughening the pericarp to enhance separation of the endosperm and bran (Pomeranz and Williams, 1990). Kernel elasticity decreased and resulted in a decrease of Young's modulus (Dziki et al., 2010; Glenn et al., 1991). This implies that increasing the moisture enables the separa- tion of bran from the endosperm, and this is the reason for tempering wheat grains prior to milling. Similar observations were reported by Dziki et al. (2010) for individual wheat kernels and by Wozniac and Styk (1996) for barley grains.

The 1st/2nd break streams conversely showed an increase in Young's modulus with moisture (table 5). Other than softening the endosperm, another objective of tempering wheat prior to milling is to keep the bran intact to enable easy separation during the sifting process. We observed an increase in the Young's modulus values for the break stream $(p \leq 0.05)$. Because the break stream is made up of bran and flour, the adhesion and cohesion forces are not strong due to the differences in particle sizes. Therefore, with the addition of moisture to the sample, the volume of the break stream particles increased, resulting in a smaller strain produced for the same applied stress. Hence, the Young's modulus increased with an increase in the moisture content.

Increasing moisture did not have a significant effect $(\mathrm{p} \geq$ 0.05 ) on the Young's modulus of soft wheat flour (table 6). Increases in the moisture content of flour increased the interaction strength between particles. As a result, when stress was applied, the strain produced in flour decreased by a smaller margin due to the compact and cohesive nature of the flour particles, resulting in a small increase in Young's modulus. Hence, moisture did not have a significant effect on the Young's modulus of SRW flour ( $\mathrm{p} \geq 0.05$ ).

\section{COEFFICIENTS OF STATIC AND ROLLING FRICTION}

When a wheat kernel comes into contact with the break rolls during milling, it offers some resistance to the shear and compressional forces of the rolls. In DEM model development, the resistance force offered by the wheat kernel will be determined using the data from the friction coefficient values between the grain and the roll surface.

The coefficient of friction values for wheat kernels from the three classes ranged from 0.38 to 0.47 for static friction and from 0.17 to 0.24 for rolling friction (table 4). Although the friction coefficients appeared to increase with moisture addition, the effect of moisture was not significant $(p>$ 0.05). Brubaker and Pos (1965) reported that the coefficient of friction was significantly influenced by kernel moisture content. Babić et al. (2011) reported that wheat coefficient of friction values ranged from 0.32 to 0.36 depending on the 
wheat class. Similar results of a linear increase in friction coefficient with moisture were reported by other researchers for grains such as pulses (Amin et al., 2005).

Moisture content did not significantly affect $(p>0.05)$ the coefficients of static friction of the break stream samples (table 5). However, there was a significant effect $(\mathrm{p}<$ 0.05) of moisture on the rolling friction coefficient of the break stream samples. This can be attributed to the compositional variability and the wide particle size distribution of the break stream samples. The coefficients of static and rolling friction of wheat flour were in the same range (table 6), unlike wheat kernels and break streams, for which the rolling friction coefficients were lower than the static friction coefficients. This is due to the fact that flour particles are smaller than wheat kernels and break stream particles. Therefore, more compaction takes place in flour on application of force, resulting in a higher rolling friction coefficient. For wheat flour, both friction coefficients increased with moisture content. Subramanian and Viswanathan (2007) reported an increase in friction coefficient with moisture content for millet flours.

\section{COEFFICIENT OF RESTITUTION}

For the break streams and flour, only the compact tablets that rebounded back without any angular movement and had a direct impact on the metal surface were selected for calculation purposes. In the case of wheat kernels, care was taken to drop each grain in the same orientation, with the kernels striking the metal surface on their sides.

The coefficient of restitution of wheat kernels from the three classes ranged from 0.3 to 0.4 (table 4 ). There was no significant effect of moisture on the coefficient of restitution for HRW and HRS wheat kernels. However, for SRW wheat kernels, there was a significant decrease in the coefficient of restitution with increasing moisture, which could be attributed to the lower kernel hardness of soft wheat kernels. Similar observations were made by Ozturk et al. (2010) for chick pea and lentil seeds; they reported that the coefficient of restitution depended on the moisture content and drop height. However, in our experiments, the drop height was kept constant in order to simulate the fall of wheat kernels from the feed hopper onto the break roll during the milling process.

Unlike wheat kernels, the restitution value for the break streams and flour generally increased with increasing moisture (tables 5 and 6). While the coefficient of restitution increased, the variation with moisture content within a wheat class was low. The values ranged from 0.25 to 0.30 for the break stream tablets and from 0.24 to 0.40 for the flour tablets. The values for the break stream tablets were lower than for the flour tablets due to the differences in composition and particle size distribution of the materials from which the tablets were prepared. In the case of the SRW break stream and flour tablets, there was no variation in the coefficient of restitution values with moisture content, possibly because of the compact and cohesive nature of the SRW endosperm particles. However, in the case of the HRW and HRS break stream and flour tablets, there was significant $(\mathrm{p}<0.05)$ variation with moisture content.

\section{CONCLUSION}

In determining the different physical and material properties of wheat mill streams, it was observed that moisture content had a significant effect on some physical properties of the mill streams and flour (i.e., particle size and size distribution, bulk density, and tapped density) that was greater than the effect on material properties (i.e., Young's modulus, coefficients of friction, and coefficient of restitution). The variation in properties of the mill streams from different wheat classes can be attributed to differences in hardness, milling method, and growing conditions. These physical and material property values (particle size and size distribution, bulk density, coefficients of rolling and static friction, Young's modulus, and coefficient of restitution) will be used as input parameters in developing a DEM model. Using these properties, spherical particles that simulate wheat kernels and wheat mill stream particles in their behavior and properties will be created and used in the model. By taking into account the variability of these properties for different wheat classes, we can accurately predict the milling of wheat during first break milling.

\section{ACKNOWLEDGEMENTS}

We would like to thank Dr. Susan Sun (University Distinguished Professor, Kansas State University), Dr. Yong Cheng Shi (Professor, Kansas State University), and Dr. Tom Pearson (formerly with USDA-ARS, Manhattan, Kansas) for allowing us access to the instruments used for the different property measurements.

\section{REFERENCES}

AACC. (1999). 76-13.01: Total starch assay procedure (megazyme amyloglucosidase/ $\alpha$-amylase method). St. Paul, Minn.: AACC International.

Amin, M. N., Ahammed, S., Roy, K. C., \& Hossain, M. A. (2005). Coefficient of friction of pulse grains on various surfaces at different moisture content. Intl. J. Food Prop., 8(1), 61-67. http://dx.doi.org/10.1081/JFP-200048092.

AOAC. (2000). 925.10: Solids (total) and moisture in flour. In Official Methods of Analysis (17 ed.). Gaithersburg, Md.: AOAC International.

AOAC. (2006a). 920.39: Fat (crude) or ether extract in animal feed. In Official Methods of Analysis (17 ed.). Gaithersburg, Md.: AOAC International.

AOAC. (2006b). 934.01: Moisture in animal feed: Loss on drying at $95^{\circ} \mathrm{C}$ to $100^{\circ} \mathrm{C}$. In Official Methods of Analysis (17 ed.). Gaithersburg, Md.: AOAC International.

AOAC. (2006c). 942.05: Ash in animal feed. In Official Methods of Analysis (17 ed.). Gaithersburg, Md.: AOAC International.

AOAC. (2006d). 978.10: Fiber (crude) in animal feed and pet food. In Official Methods of Analysis (17 ed.). Gaithersburg, Md.: AOAC International.

AOAC. (2006e). 984.13: Protein (crude) in animal feed, forage (plant tissue), grain, and oil seeds. In Official Methods of Analysis (17 ed.). Gaithersburg, Md.: AOAC International.

ASABE. (2008). S 319.4: Method of determining and expressing fineness of feed materials by sieving. St. Joseph, Mich.: ASABE.

Babić, L., Babić, M., Turan, J., Matic-Kekic, S., Radojcin, M., Mehandzic-Stanisic, S., Pavkov, I., \& Zoranovic, M. (2011). Physical and stress-strain properties of wheat (Triticum 
aestivum) kernel. J. Sci. Food and Agric., 91(7), 1236-1243. http://dx.doi.org/10.1002/jsfa.4305.

Bharadwaj, R., Smith, C., \& Hancock, B. C. (2010). The coefficient of restitution of some pharmaceutical tablets/compacts. Intl. $J$. Pharmaceutics, 402(1-2), 50-56. http://dx.doi.org/10.1016/j.ijpharm.2010.09.018.

Boac, J. M., Casada, M. E., Maghirang, R. G., \& Harner III, J. P. (2010). Material and interaction properties of selected grains and oilseeds for modeling discrete particles. Trans. ASABE, 53(4), 1201-1216. http://dx.doi.org/10.13031/2013.32577.

Brubaker, J. E., \& Pos, J. (1965). Determining static coefficients of friction of grains on structural surfaces. Trans. ASAE, 8(1), 5355. http://dx.doi.org/10.13031/2013.40423.

Campbell, G. M., Fang, C., \& Muhamad, I. I. (2007). On predicting roller milling performance: VI. Effect of kernel hardness and shape on the particle size distribution from first break milling of wheat. Food and Bioproducts Proc., 85(C1), 7-23. http://dx.doi.org/10.1205/fbp06005.

Chang, C. S. (1988). Measuring density and porosity of grain kernels using a gas pycnometer. Cereal Chem., 65(1), 13-15.

Cleary, P. W. (2001). Recent advances in DEM modelling of tumbling mills. Minerals Eng., 14(10), 1295-1319. http://dx.doi.org/10.1016/S0892-6875(01)00145-5.

Delwiche, S. R. (2000). Wheat endosperm compressive strength properties as affected by moisture. Trans. ASAE, 43(2), 365-373. http://dx.doi.org/10.13031/2013.2713.

Dziki, D. (2008). The crushing of wheat kernels and its consequence on the grinding process. Powder Tech., 185(2), 181-186. http://dx.doi.org/10.1016/j.powtec.2007.10.012.

Dziki, D., \& Laskowski, J. (2004). Influence of kernel size on grinding process of wheat at respective grinding stages. Polish $J$. Food and Nutrition Sci., 13(1), 29-33.

Dziki, D., Laskowski, J., Siastala, M., \& Biernacka., B. (2010). Influence of moisture content on the wheat kernel mechanical properties determined on the basis of shear test. Intl. Agrophysics, 24(3), 237-242.

Fang, C. Y., \& Campbell, G. M. (2002). Effect of roll fluting disposition and roll gap on breakage of wheat kernels during first-break roller milling. Cereal Chem., 79(4), 518-522. http://dx.doi.org/10.1094/CCHEM.2002.79.4.518.

Fang, Q. (1995). Effects of physical properties of wheat and operational parameters of roller mills on size reduction. Manhattan, Kans.: Kansas State University, Deparment of Grain Science and Industry.

Fang, Q., Biby, G., Haque, E., Hanna, M. A., \& Spillman, C. K. (1998). Neural network modeling of physical properties of ground wheat. Cereal Chem., 75(2), 251-253. http://dx.doi.org/10.1094/CCHEM.1998.75.2.251.

Garnayak, D. K., Pradhan, R. C., Naik, S. N., \& Bhatnagar, N. (2008). Moisture-dependent physical properties of Jatropha seed (Jatropha curcas L.). Ind. Crops and Prod., 27(1), 123-129. http://dx.doi.org/10.1016/j.indcrop.2007.09.001.

Glenn, G. M., \& Saunders, R. M. (1990). Physical structural properties of wheat endosperm associated with grain texture. Cereal Chem., 67(2), 176-182.

Glenn, G. M., Younce, F. L., \& Pitts, M. J. (1991). Fundamental physical-properties characterizing the hardness of wheat endosperm. J. Cereal Sci., 13(2), 179-194.

http://dx.doi.org/10.1016/S0733-5210(09)80035-0.

Hareland, G. A. (1994). Evaluation of flour particle-size distribution by laser diffraction, sieve analysis, and near-infrared reflectance spectroscopy. J. Cereal Sci., 20(2), 183-190. http://dx.doi.org/10.1006/jcrs.1994.1058.

Horiba. (2008). User manual: LA-910 laser scattering particle size distribution analyzer. Kyoto, Japan: Horiba.
Jayas, D. S., \& Cenkowski, S. (2007). Grain property values and their measurement. In A. S. Majumdar (Ed.), Handbook of Industrial Drying (pp. 575-600). Boca Raton, Fla.: CRC Press.

Jirsa, O., Hruskova, M., \& Svec, I. (2008). Near-infrared prediction of milling and baking parameters of wheat varieties. J. Food Eng., 87(1), 21-25.

http://dx.doi.org/10.1016/j.jfoodeng.2007.09.008.

Kingsly, A. R. P., \& Ileleji, K. E. (2009). Sorption isotherm of corn distillers dried grains with solubles and its prediction using chemical composition. Food Chem., 116(4), 939-946. http://dx.doi.org/10.1016/j.foodchem.2009.03.050.

Mateos-Salvador, F., Sadhukhan, J., \& Campbell, G. M. (2011). The normalised Kumaraswamy breakage function: A simple model for wheat roller milling. Powder Tech., 208(1), 144-157. http://dx.doi.org/10.1016/j.powtec.2010.12.013.

Neel, D. V., \& Hoseney, R. C. (1984). Sieving characteristics of soft and hard wheat flours. Cereal Chem., 61(4), 259-261.

Niernberger, F. F. (1966). Roll diameter and speed: Their effects on first break grinding of wheat. Manhattan, Kans.: Kansas State University, Department of Grain Science and Industry.

Oleson, B. T. (1994). World wheat production, utilization, and trade. In W. Bushuk, \& V. F. Rasper (Eds.), Wheat: Production, Properties and Quality (pp. 1-11). London, U.K.: Blackie Academic and Professional.

Ozturk, T., \& Esen, B. (2008). Physical and mechanical properties of barley. Agricultura Tropica et Subtropica, 41(3), 117-121.

Ozturk, I., Kara, M., Uygan, F., \& Kalkan, F. (2010). Restitution coefficient of chick pea and lentil seeds. Intl. Agrophysics, 24(2), 209-211.

Pasikatan, M. C., Milliken, G. A., Steele, J. L., Haque, E., \& Spillman, C. K. (2001). Modeling the energy requirements of first-break grinding. Trans. ASAE, 44(6), 1737-1744. http://dx.doi.org/10.13031/2013.6986.

Patwa, A., Malcolm, B., Wilson, J., \& Ambrose, R. P. (2014). Particle size analysis of two distinct classes of wheat flour by sieving. Trans. ASABE, 57(1), 151-159.

Pomeranz, Y., \& Williams, P. C. (1990). Wheat hardness: Its generic, structural, biochemical background, measurement, and significance. In Y. Pomeranz (Ed.), Advances in Cereal Science and Technology, Vol. 10 (pp. 471-557). St. Paul, Minn.: AACC International.

Subramanian, S., \& Viswanathan, R. (2007). Bulk density and friction coefficients of selected minor millet grains and flours. $J$. Food Eng., 81(1), 118-126. http://dx.doi.org/10.1016/j.jfoodeng.2006.09.026.

Turnbull, K. M., \& Rahman, S. (2002). Endosperm texture in wheat. J. Cereal Sci., 36(3), 327-337. http://dx.doi.org/10.1006/jcrs.2002.0468.

Urena, M. O., Galvan, M. G., \& Teixeira, A. A. (2002). Measurement of aggregate true particle density to estimate grain mixture composition. Trans. ASAE, 45(6), 1925-1928. http://dx.doi.org/10.13031/2013.11407.

Wozniak, W., \& Styk, W. (1996). Internal damage to wheat grain as a result of wetting and drying. Drying Tech., 14(2), 349-365. http://dx.doi.org/10.1080/07373939608917101.

Wrigley, C. W. (2009). Wheat: A unique grain for the world. In K. A. Khan, \& P. R. Shewry (Eds.), Wheat Chemistry and Technology (pp. 1-17). St. Paul, Minn.: AACC International.

Yap, S. F., Adams, M. J., Seville, J. P., \& Zhang, Z. (2008). Single and bulk compression of pharmaceutical excipients: Evaluation of mechanical properties. Powder Tech., 185(1), 1-10. http://dx.doi.org/10.1016/j.powtec.2007.09.005.

Zoerb, G. C., \& Hall, C. W. (1960). Some mechanical and rheological properties of grains. J Agric. Eng. Res., 5(1), 83-93. 